\title{
GAMBARAN KESEJAHTERAAN SUBJEKTIF LANSIA YANG AKTIF DALAM KEGIATAN RELIGIUS
}

\author{
Novi Kosalina \\ Program Studi Psikologi Universitas Bunda Mulia \\ kosalinanovi@gmail.com
}

\begin{abstract}
There were images that older adults are predominantly senile, unproductive, poor in health, and useless. In fact, there are many older adults who still optimally function, such as on religious activities. Religious activities give positive impact for these older adults life. Having social support from religious community and give sense of meaning and purpose. Older adults can have subjective wellbeing, which can decrease depression risk and health problems. Subjective wellbeing is evaluation about one's happiness, on emotional, psychological, and social aspect. This research was conducted as an effort to understanding in much deeper and more comprehensive way about subjective wellbeing in older adults who is active in religious activities. There are four subjects that involved in this research. They were 67-77 years old, widowed, and active in religious activities. This research is using interview method, conducted in about one month. Results indicate that all subjects have subjective wellbeing.
\end{abstract}

Keyword: Older Adults, Subjective Well-Being, Religious Activities

\begin{abstract}
ABSTRAK
Lansia sering digambarkan dengan pikun, tidak produktif, sering sakit, dan tidak berguna. Pada kenyataannya, banyak lansia yang masih dapat berfungsi secara optimal dalam kesehariannya. Salah satu kegiatan yang bisa mereka lakukan adalah dengan terlibat dalam kegiatan religius. Aktivitas religius memberi dampak positif bagi lansia dalam menjalani kehidupannya, yaitu melalui dukungan sosial dari komunitas keagamaan dan memberikan perasaan bermakna dan memiliki tujuan hidup. Sehingga kemudian lansia dapat memiliki kesejahteraan subjektif, yang dapat menurunkan risiko depresi dan masalah kesehatan. Kesejahteraan subjektif adalah evaluasi seseorang mengenai kebahagiaan dalam aspek emosional, psikologis, dan sosial. Penelitian ini dilakukan dengan tujuan untuk memperoleh pemahaman yang lebih mendalam dan menyeluruh mengenai kesejahteraan subjektif lansia yang aktif dalam kegiatan religius. Terdapat empat subjek yang terlibat dalam penelitian ini, yang berusia 67-77 tahun, janda, dan aktif dalam kegiatan relijius. Penelitian ini menggunakan metode wawancara selama satu bulan. Hasilnya mengindikasikan semua subjek memiliki kesejahteraan subjektif.
\end{abstract}

Kata kunci: Lansia, Kesejahteraan Subjektif, Kegiatan Religius

\section{PENDAHULUAN}

Proses penuaan (aging process) merupakan proses alami yang tidak dapat dielakkan dan berpengaruh terhadap segi kehidupan fisik, mental, sosial, dan spiritual. Seorang lansia sukses dalam tahapan perkembangannya digambarkan memiliki rasa integritas atau puas, yang ditandai dengan merasakan kepuasan dari hasil hubungan yang diperoleh, menikmati hidup bersama anak cucu, merasa bahagia karena telah memberi sesuatu yang berarti bagi generasi berikutnya (Hurlock dalam Hartati dan Andayani, 2004).

Mencapai usia tengah baya dan lansia yang aktif secara fisik semakin sulit dikarenakan dua hal. Pertama, kelompok usia ini mengalami pertumbuhan yang belum pernah terjadi sebelumnya. Kedua, aktivitas fisik telah hilang hampir pada setiap aspek 
kehidupan, dan sebagian besar lansia tidak memperoleh cukup olahraga (Godbey, Burnett-Wolle, \& Chow, 2007).

Pandangan ageisme, yaitu prasangka terhadap orang lain berdasarkan usia, terutama pada lansia, yang mempersepsikan lansia sebagai orang yang kaku, tidak cekatan, atau jika mempekerjakan orang tua tidak efektif. Lansia dihindari karena dianggap mudah lupa dan membosankan. Lansia disingkirkan dari kehidupan keluarga oleh anak yang memandang lansia sakit, buruk, dan parasit. Lansia dianggap tidak dapat berpikir jernih, mempelajari hal yang baru, berkontribusi pada komunitas, dan memegang tanggung jawab pekerjaan (Santrock, 2004).

Beberapa asumsi yang salah mengenai lansia: (1) Lansia dianggap kesepian dan depresi, kenyataannya kebanyakan lansia mudah bergaul dan "hidup". Beberapa memang tidak, tetapi beberapa anak muda juga ada yang demikian; (2) kebanyakan lansia hidup di panti jompo. Kenyataannya 4 dari 100 lansia yang berusia 65 tahun dan yang lebih tua tinggal di panti jompo.

Dalam penelitian longitudinal yang diikuti empat generasi selama 23 tahun, terdapat lansia yang memiliki emosi negatif seperti gelisah, kebosanan, kesepian, tidak bahagia, dan derajat depresi meningkat seiring usia. Di lain pihak, ada juga lansia yang merasakan emosi positif, seperti bersemangat, minat, bangga, dan rasa berhasil cenderung stabil sampai akhir hidup (Charles, Reynols, dan Gatz, dalam Papalia et al., 2004). Emosi negatif, merupakan hasil dari akumulasi penderitaan, kemunduran, kehilangan, dan kekecewaan. Sedangkan emosi positif, terbentuk saat seseorang merasa dirinya berhasil dan mampu untuk mengontrol perubahan yang terjadi seiring dengan bertambahnya usia kronologis, dengan memfokuskan pada kekuatan dan kemampuan yang dimiliki.
Pada lansia, jumlah orang yang menderita depresi meningkat secara tetap sampai usia 80 tahun sekitar $10 \%$ (Greist dan Jefferson dalam Hartati dan Andayani, 2004). Lansia akan menghadapi banyak duka cita karena kehilangan seseorang yang dicintai atau orang dekat. Terlebih lagi apabila akan menghadapi masa pensiun, kehilangan pekerjaan, perubahan kedudukan yang sering menimbulkan gangguan emosional berupa kecemasan dan depresi terselubung (Hawari dalam Hartati dan Andayani, 2004). Perasaan terasing dan penolakkan dari anggota keluarga merupakan tekanan psikologis bagi lansia. Depresi merupakan masalah kesehatan mental yang paling sering dihadapi lansia dan meningkat $20 \%$ pada individu yang berusia 65 tahun dan lebih tua (Butler, Lewis, \& Sunderland dalam Cummings, 2002).

Successful adaptation (Baltes dan Cartensen dalam Godbey, BurnettWolle, \& Chow, 2007) dapat diperoleh dengan meminimalkan kondisi yang membatasi dan meningkatkan kesempatan untuk berkembang. Konsep ini penting untuk dua alasan. Pertama, secara akurat mendeskripsikan kemampuan lansia. Meskipun sebagian besar orang yang berusia lanjut diasosiasikan dengan penurunan, namun pada rentang usia ini pertumbuhan masih terjadi, terutama pada aspek seperti perkembangan kognitif dan afektif (Schaie dan Willis dalam Godbey et al., 2007). Kedua, perlu dipahami cara orang untuk memaksimalkan usia mereka bervariasi bergantung pada kemampuan dan motivasi yang berubah seiring waktu.

Penelitian yang dilakukan Chow (dalam Godbey et al., 2007) menemukan bahwa aktivitas waktu luang mengkontribusikan hal positif pada kesehatan lansia, dibanding aktivitas seperti pekerjaan rumah tangga atau pekerjaan formal. Hal ini meningkatkan aspek kesejahteraan fisik, seperti 
persepsi kesehatan, fungsi fisik, kesehatan mental, vitalitas, fungsi sosial, dan pencegahan. Oleh karena itu, aktivitas waktu luang yang secara intrinsik memuaskan dan merupakan pilihan bebas dapat meningkatkan aktivitas dan menjaga kesehatan lansia.

Satcher (dalam Cummings, 2002) menekankan pentingnya kesejahteraan psikologis bagi kesehatan lansia, guna mengurangi efek gangguan mental, terutama depresi dalam populasi lansia, dan secara luas masyarakat secara keseluruhan. Kesejahteraan psikologis tidak dikaitkan dengan jumlah aktivitas sosial yang dihadiri, namun persepsi mereka terhadap tingkat dukungan sosial yang mereka terima.

Banyak penelitian mengenai kesejahteraan psikologis menyatakan bahwa dukungan sosial dapat menyediakan proteksi terhadap kesehatan yang buruk dan gangguan mental pada lansia. Keuntungan dari dukungan sosial telah dihubungkan dengan menurunnya depresi, gangguan fungsional, lebih sejahtera, serta menurunnya resiko institusionalisasi. Para peneliti menemukan ketidakpuasan dalam kontak sosial dan rendahnya dukungan secara kuat dapat memprediksikan gejala depresi (Cummings, 2002).

Orang yang lebih tua cenderung menunjukkan hubungan yang kuat antara religiusitas dengan kesejahteraan (McFadden dalam Compton, 2005). Penuaan meningkatkan partisipasi religius, karena meningkatnya integrasi, keinginan akan dukungan sosial, dan kebutuhan yang semakin besar akan penjelasan mengenai makna hidup (Stark dan Bainbridge dalam Sherkat dan Ellison, 1999).

Banyak lansia menemukan bahwa agama membantu para lansia dalam menghadapi masa sulit dan mengatasi perubahan hidup yang menyebabkan stres. Apapun masalah yang dihadapi, hampir setengah dari lansia pada suatu kelompok menyatakan mereka mengatasi masalah dengan meletakkan kepercayaan mereka pada Tuhan, dengan berdoa, dan meminta pertolongan (Koenig, George, \& Siegler dalam Perlmutter dan Hall, 1992). Agama berpengaruh secara signifikan terhadap perasaan bermakna dan tujuan hidup (sense of meaning and purpose in life) (Compton, 2005).

Perkumpulan religius

menawarkan kesempatan untuk beraktivitas sosial dan berinteraksi yang dapat menyediakan kesempatan yang baik untuk mengembangkan persahabatan. Komunitas religius merupakan sumber penting dukungan sosial informal dan pendamping emosional, dan menyediakan instrumen untuk membantu mereka yang memerlukan teman dan kenyamanan saat mengalami masalah hidup (Taylor dan Chatter dalam Sherkat dan Ellison, 1999). Kelompok religius membangun rasa kebersamaan, para anggota merasa dicintai, dihargai, dan diperhatikan; dukungan religius menjadi efektif karena adanya saling berbagi berdasarkan asas altruisme dan timbal balik, dan kepercayaan umum mengenai penderitaan dan rasa tolong menolong (Ellison, Wuthnow dalam Sherkat dan Ellison, 1999). Ketelibatan religius meningkatkan kesejahteraan melalui penyediaan dukungan sosial dan sistem kepercayaan yang menawarkan harapan dan perasaan bermakna dan tujuan hidup (Lemme, 2006).

Partisipasi dalam komunitas gereja memungkinkan pembentukkan persepsi diri yang positif melalui dukungan interpersonal dan refleksi positif dari rekan seiman. Aktivitas kebaktian privat juga dihubungkan dengan pandangan diri yang positif melalui proses pengambilan peran religius (Ellison, 1993). Hubungan sosial yang dihasilkan dari aktivitas religius dapat mengurangi dampak kecemasan dan depresi serta mencegah 
perasaan terisolasi atau kesepian (Koenig dan Larson dalam Santrock, 2003).

Kegiatan ritualistik seperti berdoa, datang ke gereja setiap minggu, dan membaca Kitab Suci tidak mengindikasikan keadaan afektif. Keadaan afektif lebih banyak dipengaruhi oleh kegiatan konkret, seperti kegiatan altruis pada orang lain, yaitu membantu semata-mata untuk kepentingan orang lain, tanpa memperhitungkan kepentingan pribadi. Pelayanan yang didasarkan pada spiritual dapat membantu klien menemukan dukungan sosial, perasaan memiliki, dan pengalaman positif pada masa yang kritis (Powers, Cramer, \& Grubka, 2007). Menurut Powers et al. (2007) sama seperti motif altruis, motif yang didasarkan pada spiritual untuk membantu orang lain juga menghasilkan perasaan yang positif. Keinginan untuk melayani Tuhan dan orang lain berguna untuk menahan perasaan negatif (misalnya emosi negatif dan gejala depresi).

Secara praktis semua agama memiliki kepercayaan dan praktek untuk membantu umatnya menghadapi kematian. Faktor paling penting yang mempengaruhi sikap individu untuk terlibat secara emosional dengan suatu agama adalah kematian. Individu yang religius yang mengintegrasikan kepercayaan religius mereka dalam gaya hidup secara umum akan menghasilkan penyesuaian yang paling baik dalam menghadapi harapan hidup yang terbatas (Carey dalam Atwater, 1983).

Peacock dan Poloma (dalam Compton, 2005) menemukan kedekatan dengan Tuhan adalah prediktor tunggal terbesar dalam mencapai kepuasan hidup yang berlaku pada setiap rentang usia. Banyak penelitian yang menemukan adanya hubungan antara kepuasan hidup dengan aktivitas religius. Kegiatan religius dan sikap berhubungan dengan kepuasan hidup dan korelasinya semakin tinggi pada lansia (Perlmutter dan Hall, 1992).

Menurut Okun dan Stock (dalam Compton, 2005) religiusitas dan kesehatan yang baik adalah dua prediktor utama dalam mengukur kesejahteraan psikologis pada lansia. Penelitian menemukan bahwa keterlibatan religius dapat meningkatkan kesehatan mental dan fisik dengan meningkatkan harga diri dan kemampuan diri, terutama pada populasi lansia dan minoritas (McIntosh dan Spilka dalam Sherkat dan Ellison, 1999).

McCullough dan Snyder (dalam Emmons dan Paloutzian, 2003) pengukuran terhadap beberapa nilai seperti (harapan, kerendahan hati, rasa syukur, kontrol diri, spiritual, pengampunan, kebijaksanaan, dan cinta kasih) menunjukkan hubungan dengan kesejahteraan fisik dan psikologis. Menurut Moberg (Reed, 1991) aktivitas religius berhubungan positif dengan kepuasan hidup dan semangat hidup.

Banyak penelitian yang menemukan bahwa individu yang religius dan terlibat dalam aktivitas religius cenderung lebih sehat, baik secara mental maupun fisik. Penelitian juga secara konsisten menemukan partisipasi yang lebih banyak dalam aktivitas religius secara signifikan berhubungan dengan lebih tinggi kesejahteraan (well-being), lebih rendah perilaku kejahatan, alkoholisme, penggunaan obat-obatan, dan masalah sosial lainnya (Donahue dan Benson dalam Compton, 2005). Menurut Lemme (2006) religiusitas secara umum berdampak positif terhadap kesehatan fisik dan umur panjang (sebagian dikarenakan gaya hidup yang lebih sehat, termasuk larangan untuk merokok dan minum minuman keras), coping behavior yang meningkatkan kesehatan mental (meliputi rendahnya tingkat depresi dan bunuh diri), serta kepuasan hidup dan kebahagiaan. 
Kesejahteraan subyektif secara singkat dapat didefinisikan sebagai evaluasi individu mengenai kebahagiaan hidupnya (Warren dan Sprott, 2000). Kesejahteraan subyektif merujuk pada evaluasi seseorang terhadap hidupnya, termasuk variabel seperti kepuasan hidup dan kepuasan perkawinan, tidak mengalami depresi dan kecemasan, serta mood dan emosi yang positif. Evaluasi seseorang mengenai hidupnya dapat berupa kognisi (misalnya ketika seseorang mengevaluasi secara sadar mengenai aspek spesifik hidupnya, seperti rekreasi). Evaluasi juga dapat berupa afeksi (seseorang mengalami mood dan emosi yang tidak menyenangkan atau menyenangkan dalam reaksi mereka menghadapi kehidupan). Oleh karena itu, individu dikatakan memiliki tingkat kesejahteraan subyektif tinggi jika merasa puas dengan kehidupannya dan sering merasa bahagia, serta jarang mengalami emosi yang tidak menyenangkan, seperti kesedihan dan kemarahan (Diener, Suh, \& Oishi, 1997).

dari dua variabel besar, yaitu kebahagiaan dan kepuasan hidup. Kebahagiaan adalah keadaan emosional seseorang dan perasaan orang mengenai dunia mereka dan diri mereka sendiri. Sedangkan kepuasan hidup adalah penilaian global mengenai penerimaan diri terhadap kehidupan mereka sendiri. Tambahan variabel yang ketiga adalah rendahnya neurotisisme, perbedaan antara pengukuran emosional dan kognitif (Compton, 2005).

Kesejahteraan subyektif yang tinggi ditemukan pada orang yang melaporkan perasaan mereka sangat senang, sangat puas dengan hidup, dan ketika tingkat neurotismenya rendah (Compton, 2005). Sebagian besar orang berasumsi keadaan eksternal dari seseorang merupakan penentu penting kesejahteraan subyektif, namun kenyataannya bahwa keadaan seperti itu hanya berpengaruh kecil pada kesejahteraan subyektif (Warren dan Sprott, 2000).

Faktor-faktor seperti kesehatan, aktivitas sosial, agama, dan budaya cukup mempengaruhi kesejahteraan subyektif seseorang. Faktor agama menurut Myers (dalam Warren dan Sprott, 2003) memberi perasaan memiliki tujuan (sense of purpose) dan makna hidup, yang membantu seseorang untuk menerima kekurangan dan kegagalan mereka dengan rasa syukur, dan menghubungkan individu dengan komunitas dan memberi rasa nyaman dengan meletakkan perspektif mengenai kehidupan setelah kematian. Sedangkan faktor-faktor yang dinilai sangat penting dalam menentukan kesejahteraan subyektif adalah cinta dan perkawinan, pekerjaan, dan kepribadian.

Enam variabel inti yang merupakan prediktor terbaik dalam memprediksi kebahagiaan dan kepuasan hidup (Argyle, Myers, \& Diener dalam Compton, 2005), yaitu: (1) harga diri yang positif, (2) rasa mempunyai kontrol, (3) ekstrovert, (4) optimisme, (5) hubungan sosial yang positif, (6) perasaan bermakna dan tujuan hidup. Variabel keenam, yaitu perasaan bermakna dan tujuan hidup seringkali diukur dengan tingkat religiusitas. Individu yang melaporkan iman kepercayaan yang kuat, pentingnya agama dalam setiap aspek kehidupan, dan sering hadir dalam ibadah biasanya melaporkan kesejahteraan yang lebih besar. Agama menyediakan dukungan sosial dan meningkatkan harga diri melalui proses verifikasi diri sebagai pribadi yang diasosiasikan dengan orang lain yang memiliki nilai yang sama. Agama juga mengurangi kecemasan dan ketakutan menghadapi kematian.

Menurut Myers, Diener, dan DeNove (dalam Lemme, 2006) prediktor seseorang memiliki subjective well-being, yaitu (1) orang yang bahagia 
dikarakteristikkan dengan memiliki harga diri positif, perasaan memiliki kontrol, dan ektraversi; (2) memiliki jaringan sosial yang suportif, dalam arti orang yang memiliki hubungan yang kuat yang dibentuk dan dijaga dengan emosi dan sosial yang positif yang mengkarakteristikkan orang bahagia. Hal ini disebabkan oleh trait positif memupuk ikatan yang kuat yang memberi dukungan terhadap kepuasan hidup; (c) orang yang bahagia terlibat dalam aktifitas yang bermakna dan menantang; (d) sumber keempat kesejahteraan adalah iman religius.

Lansia sebagai suatu fase kehidupan akhir secara alamiah. Fase yang menurut Erikson terjadi konflik antara integritas atau putus asa. Lansia dapat memiliki integritas jika ia memandang kehidupan yang telah dijalaninya sebagai sesuatu yang memuaskan tanpa penyesalan dan siap menyongsong akhir kehidupannya. Di sisi lain, ada pula lansia yang merasa putus asa. Tidak siap dengan fase akhir hidupnya atau memiliki penyesalan dalam menjalani kehidupan. Kegiatan relijius dipercaya dapat menjadi penyangga terhadap resiko negatif ini. Melalui aktivitasnya, para lansia ini dapat memperoleh dukungan sosial, perasaan bermakna, dan kesiapan dalam menghadapi kematian. Penelitian ini bertujuan untuk memperoleh gambaran kesejahteraan subjektif lansia yang aktif dalam kegiatan religius.

\section{METODE PENELITIAN}

Metode penelitan menggunakan metode kualitatif. Menurut Sukmadinata (2009), penelitian kualitatif adalah penelitian yang digunakan untuk mendeskripsikan dan menganalisis fenomena, peristiwa, aktivitas sosial, sikap, kepercayaan, presepsi, dan orang secara individual maupun kelompok. Sedangkan menurut Sugiyono (2010) menjelaskan bahwa metode penelitian kualitatif merupakan metode penelitian yang berlandaskan pada filsafat positivisme, digunakan untuk meneliti pada kondisi obyek yang alamiah (sebagai lawannya adalah eksperimen) di mana peneliti adalah sebagai instrumen kunci, pengambilan sampel sumber data dilakukan secara purposive dan snowball, teknik pengumpulan dengan trianggulasi, analisis data bersifat induktif/kualitatif, dan hasil penelitian kualitatif lebih menekan makna dari pada generalisasi.

Subjek penelitian berjumlah empat orang, yaitu lansia batasan usia 65 tahun ke atas, yang aktif dalam kegiatan religius, meliputi kegiatan ritualistik, seperti berdoa, menghadiri ibadah, dan membaca kitab suci, serta berpartisipasi dalam komunitas religius, seperti terlibat dalam pelayanan ibadah mingguan, maupun acara di luar ibadah, seperti pelayanan sosial, dan sebagainya.

Penelitian ini menggunakan metode wawancara terbuka agar penulis dapat memperoleh informasi yang sedalam-dalamnya dari subjek. Akan tetapi, metode wawancara terbuka yang dilakukan tetap menggunakan petunjuk umum wawancara.

Proses analisis data dilakukan setelah proses wawancara selesai dilakukan dengan membuat transkrip wawancara dalam bentuk verbatim dan meringkas data agar yang direpresentasikannya dapat dipahami dengan baik. Setelah itu peneliti membuat tabel refleksi dan analisis untuk mengetahui inti pembicaraan subjek. Peneliti kemudian berusaha untuk menemukan berbagai pola dan ketertarikan dari data yang berguna untuk analisis kasus individu dan kasus antar individu. Dilakukan pula coding guna mengetahui data-data penting yang dikemukakan subjek. Proses coding dilakukan per subjek terlebih dahulu dengan melakukan penomoran pada setiap baris transkrip dan memberikan 
kode-kode tertentu untuk memudahkan analisis.

\section{HASIL DAN PEMBAHASAN}

Tabel 1. Komponen Kesejahteraan Emosional

\begin{tabular}{lcccc}
\hline & E & H & T & L \\
\hline Happiness & V & V & V & V \\
Life satisfaction & X & V & V & X \\
Positive affect & V & V & V & V \\
Negative affect & V & V & V & V \\
\hline
\end{tabular}

Menurut Keyes and Magyar-Moe (2004) kesejahteraan subjektif adalah pandangan seseorang mengenai pengalaman hidupnya. Terdapat dua aspek yang terlibat, yaitu evaluasi mengenai derajat perasaan positif yang dialami atau kebahagiaan dan persepsi mengenai hidupnya secara keseluruhan yang disebut kepuasan. Aspek ini diteliti dalam kesejahteraan emosional. Dimensi lain dari kesejahteraan subjektif adalah berfungsi secara positif, yang dipelajari dalam ranah kesejahteraan psikologis dan kesejahteraan sosial.

Pembahasan yang pertama adalah mengenai kesejahteraan emosional yang yang terdiri dari persepsi kebahagiaan dan kepuasan hidup, serta keseimbangan afek positif dan negatif (Keyes dan MagyarMoe, 2005). Kebahagiaan adalah jumlah keseluruhan emosi positif, seperti rasa senang dan afeksi yang seseorang rasakan ditambah dengan evaluasi kognitif mengenai kepuasan seseorang terhadap kehidupannya secara global atau secara spesifik, seperti terbatas pada aspek pernikahan, pekerjaan, dan komunitas. Afek didefinisikan sebagai sesuatu yang menimbulkan emosi, bukannya kognisi atau pikiran dan dihasilkan dari gabungan kondisi mental atau elemen pengontrol penting dalam sistem emosional (Kazdin, 2000).
Subjek E menunjukkan afek positif dan negatif tanpa berlebihan. E mengakui bahwa kehidupannya tidak selalu bahagia, ada kalanya E merasa sedih dengan masalah yang dihadapinya. E merasakan melalui pergaulannya di gereja membuat $\mathrm{E}$ merasa bahagia dan dengan melihat bahwa ada orang yang hidupnya lebih menderita membuatnya dapat bersyukur dengan kehidupan yang dijalaninya saat ini.

Subjek $\mathrm{H}$ menunjukkan bahwa dirinya bahagia, karena ia dapat menerima bahwa dirinya kini sudah berusia lanjut, namun tetap mempunyai semangat dalam hidup. $\mathrm{H}$ merasa bahagia dengan kekuatan yang ia miliki, karena ia merasakan penyertaan Tuhan dalam kehidupannya. Hal lain yang juga membuat $\mathrm{H}$ merasa bahagia adalah karena $\mathrm{H}$ memiliki hubungan yang baik dengan saudara-saudaranya. $\mathrm{H}$ juga menunjukkan emosi positif saat ia dapat membantu orang lain.

$\mathrm{T}$ merasakan kebahagiaan, terlepas dari kehidupan yang dialami tidak selamanya mulus. T menganggap bahwa kebahagiaan tidak selalu ditentukan oleh faktor ekonomi, asalkan manusia bersandar kepada Tuhan. T merasakan kebahagiaan karena anakanaknya memiiki keimanan terhadap Tuhan.

L menyatakan bahwa dirinya merasa berbahagia dengan kehidupannya. Alasan L berbahagia antara lain adalah karena dapat melayani dan berkumpul dengan teman-temannya. Kepuasan hidup mewakili pengukuran jangka panjang kehidupan seseorang (Keyes dan Magyar-Moe, 2004) atau evaluasi kognitif mengenai kepuasan seseorang terhadap kehidupannya secara global atau secara spesifik, seperti terbatas pada aspek pernikahan, pekerjaan, dan komunitas (Diener dan Dean, 2007).

Ada beberapa hal dalam kehidupan yang ingin $\mathrm{E}$ ubah, diantaranya masalah finansial anak dan 
berharap kehidupan keluarga bahagia dan tentram, hal itu menunjukkan bahwa E tidak memiliki kepuasan hidup. E juga merasa tidak puas dengan dirinya, ia merasa ingatannya terlalu kuat, sehingga ia sulit melupakan kejadian yang tidak menyenangkan.

$\mathrm{H}$ merasa puas dan menikmati kehidupan yang ia jalani sekarang, dan keinginannya saat ini adalah untuk berbagi dengan orang lain. T merasa di luar segala musibah yang menimpa dirinya, $\mathrm{T}$ merasa bahwa hidup yang dijalani indah dan tidak ada rasa penyesalan. L menyesali bahwa ia menikah dengan pria yang tampan karena menurutnya ia merasa sulit untuk menjaga suaminya tesebut dan seringkali merasa sakit hati. L menyatakan bahwa seringkali ia merasa kesepian dan ingin untuk menjalin hubungan kembali dengan lawan jenis.

Berdasarkan hasil wawancara yang dilakukan terhadap $\mathrm{E}, \mathrm{H}, \mathrm{T}$, dan $\mathrm{L}$, ditemukan bahwa keempat subyek merasakan kebahagiaan. Sedangkan ditemukan kepuasan hidup pada subyek $\mathrm{H}$ dan $\mathrm{T}$, namun tidak pada subyek $\mathrm{E}$ dan L.

Tabel 2. Komponen Kesejahteraan Psikologis

\begin{tabular}{lcccc}
\hline & E & H & T & L \\
\hline Penerimaan diri & V & V & V & V \\
Hubungan yang positif & $\mathrm{V}$ & V & V & V \\
dengan orang lain & & & & \\
Otonomi & V & V & V & V \\
Tujuan hidup & V & V & V & V \\
Pertumbuhan personal & V & V & V & V
\end{tabular}

Kesejahteraan psikologis berfokus pada level individual. Kesejahteraan psikologis terdiri dari: penerimaan diri, hubungan yang positif dengan orang lain, otonomi, penguasaan lingkungan, tujuan hidup, dan pertumbuhan personal.
Penerimaan diri adalah kriteria yang ditandai dengan perasaan positif terhadap dirinya sendri, seperti menunjukkan perilaku positif terhadap diri sendiri, mengenali dan menerima aspek-aspek yang ada pada diri, termasuk aspek personal yang tidak menyenangkan.

E mengenali dan menerima aspek-aspek yang ada pada dirinya baik yang positif maupun negatif, termasuk kenyataan bahwa ia kini sudah berusia lanjut dan $\mathrm{E}$ memiliki kebanggaan bahwa dirinya masih dapat melakukan pelayanan keagamaan. Pengenalan diri E dengan mengetahui bahwa dirinya merupakan orang yang senang bergaul dan tidak menyukai kesendirian.

$\mathrm{H}$ menyadari usianya yang sudah senja, mengakui bahwa dirinya mengalami penurunan kemampuan, baik dari segi fisik maupun ingatan. Kesadaran bahwa dirinya sudah menginjak usia lanjut dan mengalami penurunan kemampuan, membawa $\mathrm{H}$ untuk mengoptimalkan diri dengan mencari pemecahan dalam menyesuaikan diri dengan penurunan tersebut tanpa merasa kecewa.

$\mathrm{T}$ menerima bahwa ia harus mengalami musibah, yaitu harus kehilangan anak sulung dan suaminya. $\mathrm{T}$ menerima meninggalnya anaknya dan juga suaminya, sebagai masa lalu yang dipandang secara positif, serta berhasilan anak-anaknya menamatkan sekolah sebagai berkat dari Tuhan. $\mathrm{T}$ menyadari kekurangan dan tidak memaksakan diri, serta tidak menyesali kehidupan yang dijalani

L merupakan anak angkat yang tidak mengetahui orang tua kandung, dan memiliki pandangan yang positif terhadap masa lalunya tersebut. L mengetahui aspek-aspek dalam dirinya, yaitu L merasa bahwa dirinya merupakan sosok wanita yang aktif dan tidak suka bekerja di dapur. L menerima dirinya sebagai seorang ibu dari empat anak, yang telah menjadi janda, karena 
suaminya telah meninggal. L kini berusia 77 tahun, ia menggambarkan dirinya sebagai orang yang optimis. L merupakan penderita kanker payudara, yang telah melakukan operasi pengangkatan payudara setahun yang lalu. L menerima bahwa ia telah mengalami penurunan fisik dan tidak memaksakan diri untuk ikut melayani ke luar kota lagi. L menggambarkan dirinya seorang seorang yang muda, cantik, bahagia, dan centil, dan juga L menyadari bahwa dirinya kini sudah menginjak usia senja, namun tetap memandang positif terhadap dirinya.

Hubungan yang positif dengan orang lain terdiri dari kemampuan untuk menanamkan dan menghadirkan kehangatan, kepercayaan, keakraban dengan orang lain. Peduli terhadap kesejahteraan orang lain, dan mampu untuk berempati, bekerja sama, dan mengerti dengan orang lain (Keyes and Magyar-Moe, 2004). Hubungan positif dengan orang lain, melibatkan kekuatan diri, kesenangan, dan kenikmatan untuk berhubungan dekat dengan orang lain, ditandai dengan keintiman, dan rasa sayang.

E memiliki hubungan sosial yang terjalin sejak lama, menunjukkan bahwa E dapat menjaga hubungan sosialnya dengan baik. Melalui hubungan persahabatan dengan orang lain, E memperoleh kesenangan dan kenikmatan untuk behubungan dengan orang lain.

$\mathrm{H}$ menyatakan bahwa dirinya memiliki kelompok pertemanan yang tersebar di banyak tempat. $\mathrm{H}$ peduli dengan kesejahteraan orang lain dan mampu untuk berempati, sehingga $\mathrm{H}$ berusaha membantu orang lain, tidak saja secara materi tapi juga non-materi. $\mathrm{H}$ merupakan orang yang humoris dan disenangi oleh teman-temannya. Hubungan $\mathrm{H}$ tidak saja dengan orang seusianya, namun $\mathrm{H}$ juga dapat menjalin hubungan positif dengan orang yang lebih muda darinya.
$\mathrm{T}$ menunjukkan kepeduliannya terhadap orang lain dengan mau mendampingi karyawannya untuk belajar menjahit, demi masa depan karyawannya tersebut. L merasa senang jika ada orang yang dapat ia ajak bicara, dan mau mendengar keluh kesahnya. L merasa bahwa ia dapat berhubungan dengan siapa saja, peduli dengan orang lain, serta terbuka untuk meminta maaf jika berbuat salah.

Menurut Ryff dan Singer (2003) otonomi adalah kapasitas untuk mengikuti kepercayaan dan keyakinan personal meskipun harus bertentangan dengan kepercayaan konvensional. Seseorang yang berotonomi memiliki cinta, dukungan, dan penerimaan dari orang lain yang diinternalisasikan yang membantu mereka untuk bertindak sesuai dengan situasi yang ada (Johnson, 2006).

Otonomi dikaitkan dengan pemenuhan tanggung jawab, dalam hal ini $\mathrm{E}$ menunjukkan bahwa ia bertanggung jawab untuk mengurus cucunya, meskipun harus mengurangi keaktifannya di gereja. Otonomi juga dihubungkan dengan kemandirian dalam masyarakat, dalam hal ini $\mathrm{E}$ mengungkapkan bahwa dirinya adalah orang yang mandiri. Otonomi dikaitkan dengan kemampuan untuk bertahan terhadap tekanan sosial dan pola pikir, dan mengarahkan, serta mengevaluasi tindakan berdasarkan standar dan nilai yang terinternalisasi. E menunjukkan keotonomiannya dengan dirinya tetap pada prinsip dan menghindari meminta nasehat dari orang lain, kecuali anakanaknya. Keotonomian E ditunjukkan dengan memiliki cinta, dukungan, dan penerimaan terhadap anaknya yang sedang mengalami kesulitan ekonomi, dengan memakai uang simpanannya untuk melunasi utang anaknya. E dapat menguasai dirinya agar tanggung jawabnya sebagai majelis gereja dapat dijalankan dengan baik, meskipun $\mathrm{E}$ 
baru saja kehilangan suaminya karena meninggal.

$\mathrm{H}$ sedari muda memiliki prinsip yang sudah terinternalisasi dan dapat mempertahankan prinsip tersebut, meskipun ada orang lain yang tidak sependapat dengan dirinya. T memiliki prinsip dan keyakinan sendiri dan tidak mudah percaya dengan perkataan orang lain karena $\mathrm{T}$ merasa setiap orang memiliki kekurangan, dan yang paling tahu kekurangan orang adalah Tuhan.

L merasa dirinya adalah orang yang mandiri. Belajar dari pengalaman kehidupannya, L berniat untuk tidak seperti mertuanya dalam mendidik anaknya. Membebaskan anak-anaknya dalam memilih kegiatan yang ingin dilakukan.

Penguasaan lingkungan meliputi kemampuan untuk mengatur masalah sehari-hari, mengontrol masalah yang disebabkan aktivitas eksternal, memanfaatkan kesempatan yang ada secara efektif, dan memilih atau membuat konteks yang sesuai dengan kebutuhan personal.

E menunjukkan bahwa dirinya mampu untuk mengatur waktu dalam kehidupannya, dengan tetap memenuhi tanggung jawabnya, namun tetap mempunyai waktu untuk dirinya sendiri, yaitu dengan ke gereja, beribadah dan bertemu dengan teman sebayanya. E mengetahui bahwa tujuan hidupnya adalah untuk memperoleh kebahagiaan dan kerukunan bersama keluarga dan untuk mencapai hal tersebut, E mengetahui bahwa E perlu saling pengertian diantara anggota keluarga.

Saat $\mathrm{H}$ mengalami kejenuhan dengan kegiatan rutinitas, $\mathrm{H}$ mencari kegiatan yang baru agar terus ada kesibukkan. $\mathrm{H}$ menyadari bahwa orang seusianya harus dapat menahan diri agar tidak terlalu aktif, karena jika terjadi hal-hal yang tidak diinginkan yang rugi adalah diri sendiri. $\mathrm{H}$ juga menunjukkan bahwa dirinya mampu menempatkan dirinya sebagai seorang kakak, yang dapat dihormati dan dimintai pendapat. $\mathrm{H}$ menyadari kebutuhannya dan keinginannya dan $\mathrm{H}$ mampu bertindak sesuai sehingga memperoleh apa yang dibutuhkannya dari lingkungan. Penguasaan lingkungan bukan saja semata-mata untuk kebutuhan personal, namun $\mathrm{H}$ menunjukkan bahwa ia dapat mengatur orang di sekitarnya agar membantu orang lain. $\mathrm{H}$ dapat mengendalikan diri di situasi genting dan menularkannya ke orang lain.

$\mathrm{T}$ dapat memanfaatkan situasi secara efektif sehingga memperoleh uang yang dia butuhkan untuk membeli kebutuhan pokok. $\mathrm{T}$ mengetahui cara agar dirinya dapat meningkatkan pengetahuannya dalam bidang fashion dan cara agar dirinya tidak mengalami kejenuhan dalam hidup. T menunjukkan penguasaan lingkungannya dengan meminta kepada temannya untuk mengijinkan $\mathrm{T}$ bekerja di tempat temannya tersebut agar pekerjaannya dapat lebih ringan dan cepat.

L mengetahui keinginannya untuk memiliki pendamping lagi, untuk itu $\mathrm{L}$ melakukan usaha untuk memperoleh keinginannya tersebut. $\mathrm{L}$ ingin memiliki pendamping untuk tempat ia bercerita, dan berkomunikasi, bukannya seks. L mengetahui apa yang diinginkannya untuk prosesi pemakamannya nanti dan L menyatakan bahwa dirinya siap jika dipanggil Tuhan. Saat L merasa sedih, L tidak terlarut, L mencari kesibukan dan kesenangan sehingga kesedihannya bisa terlupakan.

Tujuan dalam hidup terdiri dari tujuan dan objektifitas untuk hidup, termasuk adanya perasaan terarah. Orang yang tujuan hidupnya tinggi melihat kehidupan sehari-hari sebagai cara untuk mencapai tujuan, sehingga orang ini akan melihat kehidupannya saat ini dan di masa lalu sebagai hal yang bermakna (Keyes and MagyarMoe, 2004).

E menunjukkan bahwa dirinya memiliki tujuan dan objektifitas untuk 
hidup, E menginginkan keluarganya memperoleh kebahagiaan. Fokus kehidupan E adalah keluarga. Sebagai seorang ibu dan seorang nenek, subjek $\mathrm{H}$ memiliki tujuan agar keluarganya memperoleh kasih sayang dan mengagumi dirinya. Tujuan hidup membuatnya bertahan dan menguatkan ketika menghadapi masalah, melalui pengalaman hidup, $\mathrm{H}$ belajar untuk semangat dalam menghadapi kehidupan. Tujuan hidup $\mathrm{T}$ adalah bisa mengikut Tuhan sampai dia meninggal, dan melayani Tuhan dalam pelayanannya di gereja. L ingin bertemu dengan cinta pertamanya untuk melihat rupanya. L memandang masa lalunya sebagai hal yang bermakna dan indah.

Pertumbuhan personal merefleksikan usaha untuk mengembangkan kemampuan, bakat, dan kesempatan untuk perkembangan pribadi. Selain itu juga ditunjukkan dengan terbuka terhadap pengalaman baru dan mengidentifikasi tantangan dalam berbagai situasi (Keyes and Magyar-Moe, 2004).

Meskipun E merasa dirinya sudah tua, pertumbuhan personalnya ditunjukkan dengan keinginan untuk memperluas pengetahuan melalui membaca surat kabar. Harapannya dapat melayani sesama dan Tuhan dengan sebaik mungkin.

Subjek H yang berusia 69 tahun, merasa perlu untuk belajar bahasa, mempelajari makalah-makalah yang ada. Melalui pelayanannya di luar kota dan di pedalaman, $\mathrm{H}$ belajar banyak. $\mathrm{H}$ tidak takut dalam menghadapi tantangan, seperti minimnya air bersih dan tidak ada WC yang layak.

$\mathrm{T}$ merasa dirinya dapat mengerti orang lain, menempatkan diri dengan anak-anak muda, melihat segala sesuatu dengan positif, rendah hati. Semua hal tersebut $\mathrm{T}$ alami setelah Tuhan bentuk melalui proses jatuh bangun. T memiliki keinginan untuk mempelajari alat musik kolintang, karena menurutnya ada kesamaan antara kolintang dengan piano yang merupakan alat musik yang disukainya.

L pernah menjadi pengajar bahasa Belanda dan kini karena merasa bahasa Inggrisnya kurang baik, L belajar bahasa Inggris yang diadakan di gereja. L terbuka terhadap pengalaman baru dan tantangan dan ingin ikut terlibat langsung dalam pelayanan ke luar kota.

Berdasarkan hasil wawancara, subyek E, H, T, dan $\mathrm{L}$ memiliki kesejahteraan psikologis pada semua aspek, yaitu penerimaan diri, hubngan yang positif dengan orang lain, otonomi, penguasaan lingkungan, tujuan hidup, dan pertumbuhan personal.

Tabel 3. Komponen Kesejahteraan Sosial

\begin{tabular}{lcccc}
\hline & E & H & T & L \\
\hline Integrasi sosial & V & V & V & V \\
Kontribusi sosial & V & V & V & V \\
Kedekatan sosial & V & V & V & V \\
Penerimaan sosial & V & V & V & V \\
Aktualisasi sosial & X & X & - & - \\
\hline
\end{tabular}

Kesejahteraan sosial mewakili fenomena umum yang berfokus pada tugas sosial yang dihadapi oleh orang dewasa dalam struktur sosial dan komunitas. Kesejahteraan sosial terdiri dari integrasi sosial, kontribusi sosial, kedekatan sosial, penerimaan sosial, dan aktualisasi sosial (Keyes and MagyarMoe, 2004).

Integrasi sosial adalah evaluasi kualitas hubungan seseorang dengan lingkungannya. Integrasi terbentuk ketika seseorang merasa mereka memiliki kesamaan dengan orang lain yang dapat mewujudkan realitas sosial (misalnya tetangga) dan juga tingkat perasaan bahwa orang tersebut merupakan bagian dari komunitas dan masyarakat, serta perasaan didukung oleh komunitas (Keyes and MagyarMoe, 2004). 
Integrasi sosial yang pada $\mathrm{E}$ terlihat dari hubungannya dengan temannya dalam gereja. Hal ini dikarenakan $\mathrm{E}$ terlibat dalam kegiatan religius dengan teman seusianya, E merasa memiliki pengalaman dan masalah yang serupa dan merasa bagian dari komunitas tersebut. Selain itu, E menjalin hubungan yang baik dengan ibu-ibu muda yang ia temui saat mengantar cucunya sekolah, meskipun perbedaan usianya cukup jauh, E merasa menjadi bagian dari komunitas dan menghadirkan pertemanan di antara mereka.

Subjek $\mathrm{H}$ tidak membatasi kegiatannya dalam konteks keagamaan, namun juga terbuka terhadap kegiatan di lingkungan tempat tinggalnya. $\mathrm{H}$ aktif dalam kegiatan lansia di lingkungan, dan juga sebagai pengurus di lingkungannya. Kualitas hubungan $\mathrm{H}$ dengan sesama membuat dirinya diterima dengan baik oleh orang lain, meskipun orang tersebut berasal dari latar budaya yang berbeda. $\mathrm{H}$ membuat suatu pesta natal untuk semua umat Kristen, meskipun tidak sama aliran dengan $\mathrm{H}$. $\mathrm{H}$ mengundang mulai dari Katolik, Bethany, Bethel, dan Protestan.

$\mathrm{T}$ merasakan memiliki kesamaan dengan pegawainya yang membuat mereka dapat saling mengerti dan melengkapi. L merasa teman-teman dari komunitas keagamaan memiliki kesamaan dan dirinya mendapat dukungan.

Kontribusi sosial adalah evaluasi seseorang mengenai nilai dirinya dalam masyarakat. Termasuk juga kepercayaan bahwa orang tersebut merupakan bagian penting dalam masyarakat, dengan memiliki sesuatu yang berharga untuk diberikan kepada dunia (Keyes and Magyar-Moe, 2004).

E menunjukkan bahwa dirinya memberikan kontribusi dalam masyarakat melalui pelayanannya di gereja. E juga terlibat dalam acara yang diadakan di lingkungannya, seperti gotong royong membersihkan lingkungan. $\mathrm{H}$ merasa dirinya masih mampu membantu orang lain, misalnya mendampingi lansia lain, baik yang lebih tua maupun lebih muda, karena merasa dirinya lebih sehat. $\mathrm{H}$ juga memberikan bantuan kepada korban gempa di Lampung bersama masyarakat di lingkungannya.

$\mathrm{T}$ membantu orang lain baik secara materi maupun non-materi meskipun $\mathrm{T}$ merasa dirinya tidak hidup berlebihan. L merupakan merupakan pengurus dan aktivis gereja, bagian dokumentasi dan pelayanan ke luar. L melayani di Hati Suci, yaitu penampungan untuk anak-anak miskin dan juga melayani di Panti Werda Hana. L merasa dirinya memiliki andil dalam pembangunan gereja dan merasa senang karena diperhatikan dan dihargai andilnya. L juga membantu anaknya yang mengalami kesulitan ekonomi dengan memberikan uang dan mencarikan pekerjaan.

Kedekatan sosial merupakan persepsi mengenai kualitas, organisasi, dan operasi dunia sosial, dan termasuk juga kepedulian untuk mengetahui tentang dunia. Kedekatan sosial sejalan dengan kebermaknaan dalam hidup dan melibatkan penilaian bahwa masyarakat itu dapat dapat dimengerti, logis, dan dapat diprediksi (Keyes and MagyarMoe, 2004).

E memiliki kedekatan sosial yang ditunjukkan dengan memiliki kepedulian tentang masyarakat dan mengetahui tentang dunia. E mengetahui bahwa sikap masyarakat di Indonesia terhadap lansia belum sebaik di luar negeri, terlihat dari sarana dan prasarana yang disediakan untuk para lansia. $\mathrm{H}$ merasa bahwa perhatian terhadap lansia kurang, karena menurutnya anak kini lebih sibuk. $\mathrm{T}$ memiliki pandangan terhadap masyarakat di Jakarta, yaitu acuh, tidak seperti di desa. $T$ mempunyai persepsi bahwa masyarakat tidak ditentukan oleh tampilan luar, 
karena tampilan luar terkadang bisa menipu dan tidak menunjukkan yang sebenarnya. L menilai bahwa masyarakat pada umumnya baik jika ada butuhnya saja.

Penerimaan sosial adalah penilaian terhadap masyarakat melalui karakter dan kualitas orang lain sebagai kategori umum. Seseorang harus dapat berfungsi dalam area publik yang terdiri dari orang asing. Seseorang dikategorikan penerimaan sosialnya baik jika dapat mempercayai orang lain dan meyakini bahwa orang pada umumnya memiliki sifat yang baik dan tekun. Selain itu orang tersebut juga dapat merasa aman dengan orang lain (Keyes and Magyar-Moe, 2004).

E merasakan mendapat perhatian dari orang lain, meskipun orang tersebut terpaut usia yang jauh dari dirinya. $\mathrm{H}$ percaya bahwa dirinya harus berpikir positif mengenai orang lain, dengan begitu orang lain juga memandang positif terhadap dirinya. $\mathrm{H}$ mempercayai bahwa setiap orang pada dasarnya memiliki baik, sehingga ia merasa aman meskipun pergi dengan orang yang baru dikenalnya. T memiliki keinginan untuk membantu orang dan menguatkan temannya saat ingin bunuh diri, karena $\mathrm{T}$ dapat merasakan berkat dan pertolongan dari temannya tersebut. $\mathrm{T}$ memiliki keyakinan bahwa seseorang asalkan ada kemauan pasti dapat melakukan segala sesuatu. Hubungan L dengan orang di luar kristen cukup baik. Menurut L orang harus memperhatikan orang lain, dan tidak saling menjelekjelekan. L menyadari bahwa ada keberagaman dalam masyarakat.

Aktualisasi sosial adalah evaluasi mengenai potensi masyarakat. Ini merupakan kepercayaan bahwa masyarakat dalam tahap evolusi menuju ke arah yang lebih baik dan berpotensi dapat dilihat melalui institusi dan kewarganegaraan (Keyes and MagyarMoe, 2004). Menurut Johnson (2006) aktualisasi sosial adalah dorongan untuk mengaktualisasi potensi yang ada di masyarakat dan merasa puas dan senang dengan keadaan masyarakat yang ada saat ini.

E merasa Indonesia kurang memberi perhatian kepada para lansia, melalui sarana dan prasarana yang kurang memadai. Harapan E terhadap masyarakat pada umumnya adalah agar masyarakat dapat menjadi lebih tertib dan taat dengan aturan yang ada. Menurut $\mathrm{H}$ masyarakat mempunyai potensi untuk berubah ke arah yang lebih baik, jika memiliki kepercayaan terhadap Tuhan. Semua subyek memiliki social well-being, yaitu pada aspek integrasi sosial, kontribusi sosial, kedekatan sosial, dan penerimaan sosial. Sedangkan tidak ditemukan pada aspek aktualisasi sosial.

\section{SIMPULAN DAN SARAN}

\section{Simpulan}

Hasil penelitian yang dilakukan terhadap empat subjek, yaitu E (71 tahun), $\mathrm{H}$ (69 tahun), $\mathrm{T}$ (67 tahun), dan L (77 tahun) menunjukkan bahwa keempat subjek tersebut memiliki kesejahteraan subjektif, baik secara emosional, psikologis, maupun sosial. Kesejahteraan subjektif ini didapat karena partisipasi para subjek pada kegiatan relegiusnya memberi manfaat seperti dukungan sosial, integrasi personal, strategi coping unik, dan memberikan perasaan bermakna dan tujuan hidup.

Melalui partisipasi dalam kegiatan religius, para subjek ini memperoleh dukungan sosial. Dukungan sosial dari rekan sesama pelayanan dan melalui hubungan dengan Tuhan. Kepercayaan bahwa Tuhan selalu menyertai langkah kehidupannya.

Selanjutnya, agama juga menyediakan manfaat integrasi personal. Ketika menghadapi konflik internal, subjek dengan komitmen sprituanya 
dapat fokus pada tujuan dan perjuangan mencari makan hidup. Mereka pun dalam partisipasi komunitas gereja memperoleh persepsi diri positif.

Motif altruis yang didasarkan pada ajaran agama untuk membantu orang lain menghasilkan perasaan positif dan berguna untuk menangkal perasaan negatif. Partisipasi dalam kegiatan religius juga menyediakan strategi coping unik, berupa harapan dan optimisme. Memberi rasionalisasi saat menghadapi tekanan yang tidak diharapkan atau diinginkan, serta membantu para subjek untuk melihat suatu permasalahan dalam bingkai yang lebih besar. Percaya bahwa Tuhan tidak akan memberikan cobaan yang tidak diatasi.

Partisipasi memberikan perasaan bermakna dan tujuan hidup. Menyediakan kepercayaan dan praktek untuk membantu para subjek menghadapi kematian. Memilih dan melakukan kegiatan yang konstruktif untuk mencapai tujuan yang lebih besar yang berkontribusi pada keluarga, suku, dan alam.

\section{Saran}

Melalui penelitian ini diharapkan para lansia mempunyai pandangan dan alternatif baru mengenai aktifitas yang dapat diikuti, untuk menghabiskan waktu luang dengan kegiatan yang tidak hanya bermanfaat bagi jasmani tapi juga spiritual.

Anak-anak dari para lansia ini dapat memberi perhatian lebih kepada orangtua, karena banyak dari para lansia yang merasa kesepian dan tidak memperoleh dukungan anaknya. Oleh karena itu, diharapkan jika orangtua memiliki aktifitas yang bermanfaat, seperti di bidang keagamaan ini, anakanak dapat memberikan dukungan penuh, baik secara materi maupun nonmateri. Dukungan materi, dapat berupa uang transportasi atau mengantar orang tua pergi ke tempat ibadah, dan dukungan non-materi, berupa dukungan moral, sehingga para lansia dapat merasa tenang dalam berkegiatan.

Institusi keagamaan membuat lebih banyak kegiatan yang lebih melibatkan para lansia. Kegiatan tersebut, seperti ibadah khusus untuk para lansia, dengan topik-topik untuk menguatkan para lansia, dan masalahmasalah yang biasa dihadapi para lansia serta solusinya. Kegiatan lain, seperti senam kebugaran yang diadakan di tempat ibadah, memilih dan mengangkat para lansia yang memiliki kemampuan dan kesehatan yang memadai untuk menjadi pengurus kegiatan keagamaan, seperti menjadi majelis atau penatua, atau panita untuk suatu acara, melibatkan para lansia untuk melakukan bakti sosial, sehingga para lansia memperoleh apresiasi dan ruang untuk mengembangkan diri dan memperluas pergaulan.

\section{DAFTAR PUSTAKA}

Atwater, E. (1983). Psychology of adjustment: Personal growth in a changing world ( $2^{\text {nd }}$ ed.). New Jersey: Prentice-Hall.

Compton, W. C. (2005). An introduction positive psychology. USA: Thomson Learning.

Cumming, S. M. (2002). Predictor of psychological well-being among assisted living residents. Health and Social Work. (Vol. 27). Diambil pada Januari 8, 2008.

Diener, E., Suh, E., \& Oishi, S. (1997). Recent findings on subjective well-being. Indian Journal of Clinical Psychology. Diambil pada Februari 6, 2008. University of Illinois. www.psych.uiuc.edu/ ediener/hottopic/paper2.html

Ellison, C. G. (1993). Religious 
involvement and self-perception among black amerians. Social Forces. (Vol. 71). Diambil pada Januari $8,2008$. http://www.questia.com/read/952 49417?title=Religious\%20Involve ment\%20and\%20Self-

Perception\%20Among\%20Black $\%$ 20Americans

Emmons, R. A., \& Paloutzian, R. F. (2003). The psychology of religion. Annual Review of Psychology. Diambil pada Januari 8, 2008.

Godbey, G., Burnett-Wolle, S., \& Chow, H.W. (2007). New ideas for promoting physical activity among middle age and older adults: Physical activity can lead to successful aging. The Journal of Physical Education, Recreation, and Dance. (Vol. 78). Diambil pada Januari 8, 2008.http://www.questia.com/rea $\mathrm{d} / 5023469759$

Hartati, S., \& Andayani, T.R. (2004). Perbedaan tingkat depresi antara lansia yang tinggal dengan keluarga dan lansia yang tinggal di panti sosial Tresna Werdha "Wenning Werdaya" Ungaran. Jurnal psikologi UNDIP. 1, 78-87.

Johnson, D. W. (2006). Reacing out: Interpersonal effectiveness and self-actualization $\left(9^{\text {th }}\right.$ ed.). MA: Pearson Education.

Kazdin, A. E. (Ed.). (2000). Encyclopedia of psychology. NY: Oxford University Press.

Keyes, C. L. M. \& Magyar-Moe. J. L. (2004). The meaurement and utiility of adult subjective wellbeing. In S.J. Lopez, \& C.R. Snyder (Eds.). Positive
Psychological Assessment: A Handbook of Models and Measures. (p. 411-422). Washington, DC: American Psychological Association.

Lemme, B. H. (2006). Development in adulthodd ( $4^{\text {th }}$ ed.). Boston: Allyn and Bacon.

Papalia, D. E., Olds, S. W., \& Feldman, R. D. (2004). Human Development. $\left(9^{\text {th }}\right.$ ed.). New York: McGraw-Hill.

Perlmutter, M., \& Hall, E. (1992). Adult development and aging ( $2^{\text {nd }}$ ed.). New York: John Wiley \& Sons.

Powers, D.V., Cramer, R.J., \& Grubka, J.M. (2007). Spirituality, life stress, and affective well-being. Journal of Psychology and Theology. (Vol. 35).

Reed, K. (1991). Strength of religious affiliation and life satisfaction. Sosiological Analysis. (Vol. 52). Diambil pada Januari 8, 2008. http://www.questia.com/read/978 21329

Santrock, J. W. (2006). Human adjustment. New York: McGrawHill.

Santrock, J.W. (2003). Psychology $\left(7^{\text {th }}\right.$ ed.). New York: McGraw-Hill.

Sherkat, D. E., \& Ellison, C. G. (1999). Recent development and current controversies in sociology of religion. Annual Review of Sociology. Diambil pada Januari 8,2008 . http://www.questia.com/ $\mathrm{read} / 5001895366$

Sugiyono. (2010). Metode Penelitian Pendidikan Pendekatan 
Kuantitatif, kualitatif, dan $R \& D$. Bandung: Alfabeta

Warren, K., Ph.D. \& Sprott, Ph.D. Diambil pada, Februari 6, 2008. http://sprott.physics.wisc. edu/lectures/paper263/tsld002.ht $\mathrm{m}$ 